\title{
Slavic Generative Syntax
}

\author{
Steven Franks
}

\begin{abstract}
This article discusses major research areas in Slavic generative syntax. It begins with a short survey of topics, identifying important literature and useful resources. It then examines selected areas in more detail, specifically: (i) multiple wh-movement, (ii) secondary predication and control, (iii) agreement and coordination, and (iv) nominal structure and phases. Finally, several domains of inquiry are singled out for future research.
\end{abstract}

\section{Introduction}

This article offers a survey of the major research areas in Slavic generative syntax since the inception of the Journal of Slavic Linguistics 25 years ago. Given the number of languages concerned, the range of phenomena studied, and the diversity of approaches, the quantity of relevant publications is simply overwhelming. I must therefore be highly selective both in identifying significant problems and in describing important work on those problems. I apologize in advance to those whose scholarship does not find its way into this short survey, which of necessity reflects my personal perceptions about what the field has accomplished and where it is headed. Since my view is that the best measure of our success, as Slavic linguists, is in how well we are able to make non-Slavists sit up and take notice of "our" phenomena and analyses, the focus here will be on those areas which, in my opinion, have had the greatest impact on the thinking of syntacticians in general. This is in keeping with what I see as a major goal of the Slavic Linguistics Society and its journal, namely, the fostering of intellectual exchanges and the building of bridges between linguists of different stripes.

The paper is structured as follows: section 2 surveys changes in the field over the past quarter century and identifies some significant publications dealing with Slavic syntax written from a generative perspective; from this overview of topics, several are selected in section 3 for examination in more

\footnotetext{
* I am indebted to Catherine Rudin and an anonymous reviewer for helpful comments.
} 
detail; section 4 then describes some areas which I believe may be of increasing relevance over the next few years.

\section{A Quick Survey}

The first issue of JSL (volume 1, number 1, winter-spring 1993) was printed in December 1992. That year also marked the inauguration of the annual Formal Approaches to Slavic Linguistics meetings, which have since continued uninterrupted and result in regular FASL proceedings. FASL has been highly generative in orientation, so the topics covered in the proceedings have tended to reflect matters of current interest. Case has of course always been a matter of central concern, as can be seen in the earliest monographs in Slavic generative syntax, such as Babby $(1975,1980)$ and Chvany $(1975)$, although by the first important edited collections-Brecht and Chvany (1974) and Chvany and Brecht (1980) - the papers already dealt with quite a broad range of topics. ${ }^{1}$ The field really began to take off, however, only in the early 1990s. In 1992, at the first Ann Arbor FASL meeting (which was initially a "by-invitation-only" event), there were papers on long vs. short adjectives, clause structure and functional categories, numeral phrases, binding, and dative subjects. By the second Ann Arbor Meeting, which took place in 2001, one can note additional timely topics such as topic and focus, scrambling, (multiple) wh-fronting, and clitics, as well as classic Slavic problems such as (genitive of) negation and scrambling. The European counterpart of FASL-Formal Description of Slavic Languages (essentially German, with its biennial meetings alternating between Leipzig and Potsdam, with the so-called "0.5" or "halftime" FDSL meetings held in more diverse locations), began in 1995 and, although in general more varied in subject matter than FASL proceedings, has produced a steady stream of generative syntactic studies in its proceedings as well. ${ }^{2}$

Turning to monographs that have appeared in this window, one might single out my own Franks (1995), a (somewhat eclectic) study of parametric variation in Slavic, and Franks (2017), an (even more eclectic) exploration of how syntactic structures are mapped into representations manipulable by the morphology and phonology, largely devoted to wh-movement and clitic phenomena. ${ }^{3}$ Also noteworthy for Slavic clitics are Franks and King (2000),

\footnotetext{
1 These two collections were reprinted in 2016 and are now available for free download at https://slavica.indiana.edu/bookListings/linguistics

2 For a sociological overview which places these and other conferences in their larger context and relates them to the coming of age of the Slavic Linguistics Society, see Franks (2015a).

3 Also worth singling out for its value in the study of Bulgarian syntax is Rudin (2013), a slightly revised edition of her original 1986 book.
} 
a (somewhat descriptive) survey, and Bošković (2001), a study which tackles pervasive problems of clitic realization in the larger context of wh-fronting. Progovac (2005) examines an assortment of constructions in Bosnian/Croatian/Serbian (although focusing on her native Serbian variant) from the perspective of a highly articulated clause structure. Much less generative than his earlier work is Babby (2009), which puts forward a comprehensive model of argument structure, based on close study of selected issues in Russian verbal morphology (especially adjectives and the predicate instrumental, participles and gerunds, and infinitives). While far from exclusively about Slavic, Citko (2011) shows how multidomination structures and her system of parallel merge can accommodate a broad range of syntactic phenomena in Polish, and Pesetsky (2013) develops an innovative approach to the morphosyntax of Russian case, particularly as evidenced in numeral phrases. ${ }^{4}$ Finally, Bailyn (2012) offers a wide-ranging treatment of important constructions in Russian, bringing together much of his earlier work in an accessible and highly readable format. There are, of course, many other book length publications that concentrate on Slavic phenomena from a generative perspective, especially works comparing Slavic with English. ${ }^{5}$ With respect to control in Polish, of note are Bondaruk (2004) and Witkoś et al. (2011). Related to control, there is also considerable work on copular constructions and associated phenomena; while mostly in the form of articles, one comparative monograph with excellent coverage of the literature is Bondaruk (2013). For those interested in Russian copular sentences, a particularly useful work is Pereltsvaig (2007).

Since 1992, there have been too many dissertations dealing with diverse areas of Slavic syntax and couched within generative frameworks for me even to attempt to catalog them here. More valuable instead, might be to organize a few of them by (some subset of) topics. In doing so, I have concentrated on a handful of universities (most notably: Connecticut, Indiana, MIT, Stony Brook, and Princeton). Arnaudova (2003), Dukova-Zheleva (2010), and Lambova (2003) are all concerned with information structure in Bulgarian and the clausal architecture needed to represent focus and topic, as well as wh-movement. Stjepanović (1999), Despić (2011), and Runić (2014) all treat $\mathrm{BCS}$, extending and fleshing out ideas championed by their UConn mentor, Željko Bošković. The first shows how copy pronunciation mediates Spell-Out (in particular, lower copy pronunciation in the mapping from syntax to PF) to produce effects relevant to clitics, wh-phrases, and scrambling, the second explores the contextual notion of phasehood in the nominal domain, and the third also deals with clitics, although aimed more at dialectal variation and arguing that the facts can be understood in terms of variance in the structure

\footnotetext{
${ }^{4}$ See Witkoś (2016) for a detailed and careful review of Pesetsky's monograph.

5 Also not included here is work not in English. For an excellent recent collection of papers on Bg generative syntax, written in Bg, see however Koeva and Krâpova (2013).
} 
of NPs. Over its long history, Linguistics and Philosophy at MIT has of course produced many excellent linguists whose work treats Slavic matters and, with the influx of graduate students from the former Eastern Bloc countries (noting that the window for this JSL anniversary issue roughly corresponds to the post-Soviet period), the number of relevant dissertations has multiplied. For Slavic generative syntax, one might single out from MIT the dissertations of Gračanin-Yuksek (2007), Kučerová (2007), and Nikolaeva (2014), all supervised by David Pesetsky. Under the tutelage of Len Babby, together with Edwin Williams and Bob Freidin, Princeton produced quite a few, most notably Lavine (2000), Harves (2001), Medova (2009), and Chidambaram (2013). John Bailyn of Stony Brook University has directed a number of Slavic generative syntax dissertations, including Citko (2000), Marušič (2005), Scott (2012), LaTerza (2014), and Antonyuk (2015). Lastly, at Indiana University, I have directed the following Slavic dissertations which adopt a generative approach: Brown (1996), Lindseth (1996), Yadroff (1999), Kim (2010), and Zanon (2015a). This is to be sure a somewhat eclectic and distinctly personal selection of dissertations, although even so the titles reveal a diversity of topics. I have, moreover, not even attempted to identify doctoral work by European students, although much excellent Slavic generative syntax has come out of Germany, The Netherlands, and of course the Slavic countries, especially Poland, Slovenia, and Russia. ${ }^{6}$ It should also be borne in mind that most of these dissertations have had their leading ideas popularized through publication as articles and/or conference proceedings. A final, more sociological reflection: the flow of dissertations depends to no mean degree on the mentors at the various institutions which produce them. As people like Len Babby and myself retire from Slavic Departments (and are not replaced), those departments cease to produce dissertations in Slavic syntax. Other mentors more and more belong to Linguistics Departments. This, as I observed back in Franks (1996), is the future of Slavic linguistics, and not just so far as syntax (generative or otherwise) is concerned. We can only hope that younger Slavic syntacticians continue to be hired as general linguists and, in that capacity, attract graduate students into generative (and other kinds of) syntax.

Much has changed in how research in generative syntax is conducted, hence it is worth at this point identifying these developments and asking how they have impacted the Slavic field. Again taking 1992 as our reference point, we can roughly delimit three periods-or at least conceptual orientations-in the history of Slavic generative syntax. The bulk of work in the 1990s might be characterized as (late) government and binding (GB), while by 2000 it had shifted to a minimalist program orientation. Both of these were permeated

6 To mention just two individuals, over the years Peter Kosta (Potsdam) and Jacek Witkoś (Poznań) have trained many excellent syntacticians now working on Slavic problems from a generative perspective. 
by so-called principles and parameters thinking, although, as the simplistic parametric paradigm began to break down, increasingly less so. Work in Slavic minimalist syntax has also evolved to reflect the various prevailing trends in minimalism. It seems to me that there has been a shift away from concern with formalisms and mechanisms and towards the semantic underpinnings of the processes under examination. For lack of a better term, one might call this "semantically-informed syntax," and most new work now worries as much about explaining semantic interpretation as it does about accommodating syntactic patterns. ${ }^{7}$ A quick review of the titles of papers from recent FASL meetings, compared to those presented at earlier ones, readily confirms this shift towards semantics. At the same time, there is a growing concern for experimental syntax of various flavors, so that one often finds generative analyses supplemented by (or supplementing) research involving computational, eye-tracking, or brain imaging techniques, alongside more traditional reports of judgment and production tasks, and one often reads sophisticated generative accounts in the context of first or second language acquisition studies. ${ }^{8}$

There are many fertile areas of research in Slavic syntax. Here I simply enumerate them, leaving more detailed treatment of the most salient directions in Slavic generative syntax for the next section. In doing so, I will rely on three previous discussions of the core problem areas in Slavic syntax. As an initial point of departure, consider the following laundry list of favorite topics, from Franks (2015b): ${ }^{9}$ 7 This is as it should be, syntax being a computational system which serves to con-
nect form and meaning. The mounting dominance of semantically-informed syntax
within the generative paradigm has the added dividend of bringing syntacticians of
different theoretical ilks closer, in that, to the extent that we share concerns and as-
sumptions about semantics, research carried out under different models of syntax
becomes more relevant.

8 This too pays dividends: it increases our skills and flexibility, (in theory at least) making Slavic syntacticians more marketable.

9 This list is drawn from my unpublished SLS 10 invited talk, which provided supercategories and then, for some, cited specific phenomena which (most likely) belong to those supercategories. An anonymous reviewer suggests adding double object verbs, a topic which has indeed received considerable attention and which has larger import, especially in the context of the applicative literature. The debate over whether the dative or accusative argument is higher has been a heated one. For Russian, Bailyn (as summarized in Bailyn 2012: 140-161) has taken issue with the traditional claim (cf. especially Dyakonova 2005 for relevant arguments) that dative c-commands accusative. The answer, as the reviewer rightly points out, is most likely that "there are at least two different underlying lexical frames for verbs that take a dative and an accusative." In this vein, see also Slavkov (2008), who shows that, despite their superficial similarity, Bg countenances both double object and PP ditransitives, in that a na-phrase can either be a dative/oblique introduced high, in SpecApplP or introduced low, as a true PP. 
(1) a. Clitics

b. Scrambling and word order

c. Case and agreement

i. The second dative, dative subjects (and related phenomena)

ii. The predicative instrumental

iii. Agreement with conjoined subjects

iv. The genitives of negation/quantification/partitivity

d. Argument structure, diathesis, and voice

i. Uses of the "reflexive" morpheme

ii. Uses of the "participial" morpheme

e. Aspect

f. Wh-questions, relativization, movement

i. Multiple wh-fronting

ii. Island phenomena

iii. Left-branch extraction

iv. Across-the-board movement

g. Binding and anaphora

h. Clause structure (what is present and what is missing, in various languages)

i. Nominal structure (what is present and what is missing, in various languages)

j. Null/Silent/Unexpressed subjects

These topics are to some extent adapted from those I treated in Franks (2005), and the interested reader is referred to that chapter for an examination of what I considered, at the time, "those research areas in Slavic syntax which have generated the greatest amount of investigation within recent formal models." One should finally consult Bailyn (2006) for an excellent survey of Slavic generative syntax. Albeit somewhat more theoretically oriented, that paper concentrates on a similar set of topics. In his catalog of "recent, current and soon-to-be hot topics in Slavic syntax," originally written in 2000, Bailyn discusses wh-movement, clitics, morphosyntax and voice operations, NP/DP structure, negation, and semi-predicates. In updating his earlier perspective, he identifies as potentially "hot" the following issues: case and configuration (with these subcategories: dative subjects, case and predication, genitive case structures, the status of the high functional categories), binding, syntax, and the lexicon (with these subcategories: aspect, argument structure, and voice), and, finally, word order and optionality. He and I thus seem to be in general agreement about what has been important and about what promises to be important in the future. ${ }^{10}$

10 We also concur about sociological directions in the field (although I do not share his faith in the sympathy of cognitive scientists towards generative linguists). Bailyn 


\section{Selected Topics}

One can conclude from the preceding section that the study of Slavic syntax has a great deal to offer the general linguist and that there is a broad range of topics worthy of pursuit. The goal of this section is therefore more modest, namely, to explain what I believe to be of most interest to theoreticians, and why.

\subsection{Multiple wh-movement}

It would be no understatement to say that the publication of Rudin (1988) launched an industry of research into the multiple $w h$-fronting properties of Slavic languages. ${ }^{11}$ Although they share the requirement that all wh-phrases be fronted-so that Rudin's (1988: 449) Bg (2a), BCS (2b), and Pol (2c) look the same-the languages differ in the details:

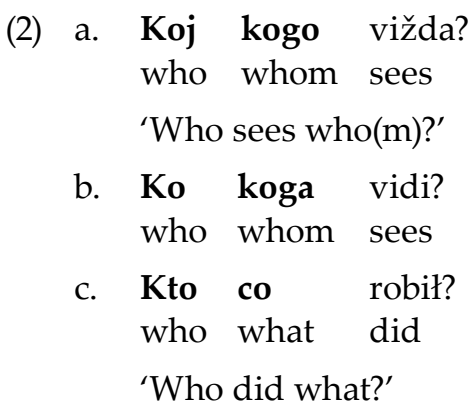

In identifying two general types of language, Rudin set a challenge for theoretical linguists. She showed that in Bg all wh-phrases behave as a unit, whereas in the other languages the first wh-phrase is in a privileged position,

(2006: 33) concludes his revision of his 2000 talk by commenting on two newer changes: "First, the functional/formal rapprochement I anticipated possibly being led by Slavic has indeed emerged, but primarily in other language areas. Secondly, most generative work in Slavic syntax in the US is now being done in Linguistics departments rather than in language departments, presenting a new dilemma-how to maintain strong ties between linguistics and language-area departments when different approaches to linguistics are often represented in the different departments. Interdisciplinary Cognitive Science groupings are the best way to provide structure bridging this potentially troublesome divide."

11 While Rudin's article was not the first to introduce Slavic multiple wh-fronting to the generative public, it did provide the first highly accessible comprehensive discussion at a time ripe for such rich and intriguing data, and as such was widely read. 
SpecCP, and the remaining ones are slightly lower in the phrase structure. Among Rudin's observations were that Bg differs from the other languages in that the wh-phrases (i) have a fixed relative order, (ii) cannot be separated by parentheticals, and (iii) undergo long distance movement as a unit. Some of her examples follow:

(3) a. *Kogo koj vižda? whom who sees

b. Koga ko vidi? whom who sees

c. Co kto robił?

what who did

(4) a. *Zavisi ot tova, koj prâv kogo e udaril. depends on this who first whom $\mathrm{AUX}_{3 S G}$ hit

$[\mathrm{Bg}]$ 'It depends on who hit whom first.' [cf. Zavisi ot tova, koj kogo prâv e udaril.]

b. Ko je proi koga udario? who $\mathrm{AUX}_{3 S G}$ first whom hit 'Who hit whom first?'

c. Kto wedtug ciebie komu co dał? who according you whom what gave 'Who according to you gave what to whom?'

(5) a. Koj kâde misliš [če e otišâl]? who where think $k_{2 S G}$ that $\mathrm{AUX}_{3 S G}$ gone 'Who do you think has gone where?' [cf. *Koj misliš če e otišâl kâde?]

b. ${ }^{*}$ Ko šta želite [da vam kupi]? who what want $2 P L$ that you buys 'Who do you want to buy you what?' [cf. Ko želite da vam šta kupi?]

c. ${ }^{*}$ Co komu Maria chce [żeby Janek kupi]? who whom Maria wants that Janek bought 'What does Maria want Janek to buy for whom?'

Differences such as these, which Rudin analyzed in GB terms of (a parametric approach to) the structure of COMP/SpecCP and the Empty Category Principle (thereby connecting the fixed who what order of Bg with Superiority in English), set the stage for subsequent minimalist approaches. Richards (2001) 
took her work as a point of departure, leading to a model of movement and specific proposals about several topics: the use of strong vs. weak features, whether the wh-phrase was absorbed into (adjoined to) IP or CP, and "tucking in" (as an implementation of the Shortest Move/Minimal Link Condition). Also significant was the observation that free(r) order reemerges among the non-initial $w h$-phrases if there are more than two, ${ }^{12}$ a fact which could be understood in terms of Richards' "Principle of Minimal Compliance"-so long as the highest $w h$-phrase satisfies Superiority, the rest are not so constrained. Here are some examples, discussed by Bošković in a series of publications:

(6) a. Kogo kak e celunal Ivan? whom how $\mathrm{AUX}_{3 S G}$ kissed Ivan

'How did Ivan kiss whom?'

b. ?*Kak kogo e celunal Ivan?

a. Koj kogo kak e celunal?
who whom how AUx ${ }_{3 S G}$ kissed
'Who kissed whom how?'

b. Koj kak kogo e celunal?

The asymmetric relationship between kogo 'whom' and kak 'how' evidenced in (6) disappears in (7), since $k o j$ 'who' moves from an A-position that is higher than either of them. ${ }^{13}$

Bošković (1999, 2002, 2010, and elsewhere) has offered several accounts of these and related data, arguing that closer inspection reveals Rudin's claim that BCS does not show Superiority effects to be incorrect. Under his widely-adopted approach, fronting can be driven not only by the familiar need to check WH features, but also by the need to check FOCUS features (cf. also Stjepanović 1999). A key insight was that these must be subject to different requirements, with superiority a hallmark of WH feature checking but not of FOCUS feature checking. The contrast between $\mathrm{Bg}(6)$ and (7) then follows if only the first wh-phrase moves to check WH features. Moreover, although both forces apply to wh-phrases in Slavic, the conditions differ in the different languages. Standard lines of variation include which functional projections bear the features involved in $w h$-fronting and the nature of those features (i.e., strong or weak), but Bošković considered several additional alternatives. In

\footnotetext{
12 The data are contested by Krapova and Cinque (2008), who demonstrate that independent factors are involved in blocking (or facilitating) particular wh orders.

13 Note that (6) shows the direct object to be higher than the adverb. This is because, according to Bošković, before undergoing A-bar movement kogo must first move to SpecAgrOP, an A-position above the adverb.
} 
earlier work he assumed both Attract and Move, ${ }^{14}$ with the WH feature on C strong hence giving rise to Attract but the FOCUS feature on the wh-phrases themselves strong, hence rendering them subject to Move. He later rejected Move, arguing that $\mathrm{WH}$ involves traditional "Attract One" but FOCUS invokes an "Attract All" option. Under either the Move or Attract All scenario, since FOCUS movement occurs from the perspective of all the moving elements equally and at the same time, it satisfies Shortest Move regardless of the order in which the various wh-phrases are fronted. Another important idea developed by Bošković and inspired by Slavic wh-fronting data is that the node with the feature driving movement (C, in this instance) can be merged in LF. He concludes this for BCS based on his observation that Superiority effects reemerge in this language whenever $\mathrm{C}$ is overt, as in Yes/No li questions (since $l i$ is in C) or in embedded contexts (cf. also the discussion around BCS (37) below). Interestingly, Stepanov (1998) argues that wh-phrases in Russian never display Superiority effects, concluding that Russian lacks wh-movement in the traditional sense, with all $w h$-fronting in that language driven exclusively by FOCUS. ${ }^{15}$

A different but likewise very important result of the study of multiple wh-movement in Slavic concerns the mapping to PF. Billings and Rudin (1996) described a constraint against consecutive homophonous wh-phrases in multiple wh-fronting languages such as Bg. This constraint renders the sequence kakvo kakvo 'what what' in (8d) unacceptable, despite koj kakvo 'who what' in (8a). ${ }^{16}$ Bošković subsequently observed the complementary distribution of the opposite realizations: ${ }^{17}$

(8) a. Koj kakvo kupi?

who what bought

'Who bought what?'

b. *Koj kupi kakvo?

\footnotetext{
${ }^{14}$ Under Move the locus of the featural deficiency is on the element which moves, whereas under Attract it is on (or near) the position where the moving element lands.

15 For more on multiple $w h$-fronting in Russian, especially from the perspective of first language acquisition, see Grebenyova (2012).

16 As an anonymous reviewer reminds me, Billings and Rudin did not actually cite the paradigm in (8), nor did they mention the last resort strategy evinced by (8c). They did however discuss comparable empirical arguments for a PF constraint (which they called SтARHом), to block sequences such as koj koj 'who who' and (na) kogo kogo '(to) whom whom'.

17 Bošković (2002: 364) notes that the phenomenon was first pointed out to him by Wayles Browne.
} 
(8) c. Kakvo obuslavja kakvo?

what conditions what

'What conditions what?'

d. *Kakvo kakvo obuslavja?

What happens when two identical fronted wh-words are contiguous, according to Bošković, is that a lower copy of the second one is pronounced: ${ }^{18}$

(9) a. Koj $\mathbf{k a k v o}_{2}$ [ kupi ${ }_{2}$ ?

b. Kakvo 1 obuslavja kakvo $\oplus_{2}$ ]?

Bošković adduces a variety of convincing arguments to confirm that this phenomenon is a matter of Spell-Out, rather than of movement per se, and can be taken in support of a particular implementation of the copy theory of movement. His account relies on my own proposals about clitics, beginning with Franks (1999) and culminating in Franks $(2014,2017)$, that exploit the observation that clitics which are not prosodically supported cannot be pronounced. I argue for a system in which OT-like constraints (e.g., in this case, Avord Homophonous SEQuences) polices the interface between syntax and PF. My more recent work explores some important differences between lower pronunciation of wh-words and of clitics. I show that the lower copy of a wh-phrase must be pronounced in its highest viable A-position; I also use this and related facts to argue for a multiattachment model as well as against successive cyclic wh-movement.

These issues, of course, represent only the tip of the iceberg. There is no room here to discuss other productive research areas such as relativization, islands, left-branch extraction (LBE), or ATB movement. In these (and other) matters, the study of multiple wh-fronting in Slavic has enriched the theoretical arsenal and empirical base of minimalist analysis.

\subsection{Secondary Predication and Control}

A great deal of ink has been spilt in examining the case of predicate adjectives in Slavic, particularly in Russian and Polish. In these languages, the adjective will either agree with its antecedent or, if agreement fails, appear in a default case. For most predicate adjectives that case is instrumental, but for the

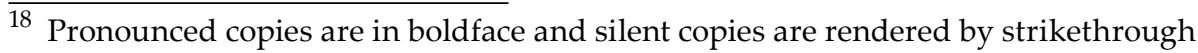
and outline font. 
"semipredicatives" sam 'alone' and odin 'one' it is dative instead. ${ }^{19}$ Here I put aside the complex issues of what the default case is and why, concentrating instead on questions raised by the semipredicatives and the so-called "second dative." ${ }^{20}$ Since Comrie's seminal 1974 paper, this topic has been explored in a vast body of research (including much of my own, detailed accounts starting with Franks 1995 and ending with 2014c). Here are four of Comrie's original examples, with PRO added to mark the infinitival subject and clause boundaries labelled as CP and TP:

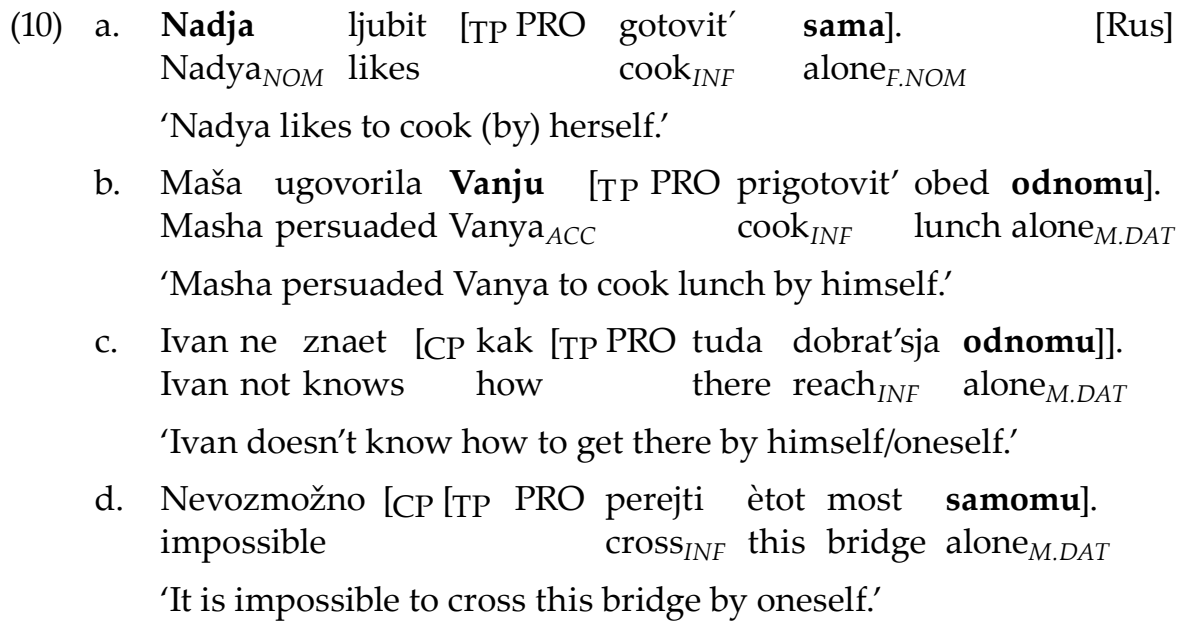

The theoretical significance of this construction relates to the fact that agreement seems to track obligatory control (OC). That is, in (10a) nominative Nadja is able to transmit its case to sama, but this fails for some reason in the other examples. In (10d), which is an instance of arbitrary control, there is of course no antecedent to transmit its case. So one might take these as endpoints, epitomizing as Landau (2008) puts it "two routes" for establishing the controller of PRO: OC leads to agreement and arbitrary control leads to a default dative. Interestingly, (10c) patterns with the latter regardless of interpretation, and, even more interestingly, (10b) does also, despite the fact that the accusative object Vanju is an obligatory controller of the embedded infinitive. One might therefore imagine that PRO can function in one of two ways, an essentially

\footnotetext{
19 Another difference is that whereas the instrumental is often optional even when agreement is also viable (in Russian but not Polish), the dative is always obligatory whenever possible. See Pereltsvaig (2007) and Richardson (2007) for in-depth discussions of the predicate instrumental.

20 I also just discuss Russian. The relationship between predicate adjective agreement and control in Polish is treated in a series of works by Witkoś (e.g., Witkoś 2010, Witkoś et al. 2011).
} 
anaphoric one in which it mediates in passing the case properties of its controller to the secondary predicate and an essentially pronominal one in which it becomes endowed with its own, independently determined case, here presumably dative (with which the semipredicative then agrees). Fleshing this story out constitutes one approach to the problem. But others abound. In the remainder of this section, I lay them out briefly.

One major issue is surveyed in Franks (2014b), namely that of endowing PRO with case. While not a possibility entertained under GB, this seems necessary if the dative semipredicative in $(10 \mathrm{~b}-\mathrm{d})$ is agreeing with PRO. So far as I am aware, minimalist accounts (e.g., Landau 2008) all invoke dative PRO, and most also allow PRO to agree in case with its controller under obligatory control. Nonetheless, the ultimate antecedent of PRO can be very far away.

This is shown in (11), which involves a chain of four instances of PRO (or five, if the nominal obeščanie 'promise' also has one):

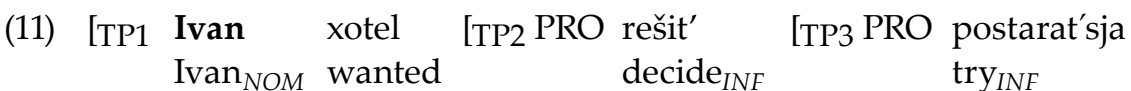

$$
\begin{aligned}
& \text { [TP4 PRO dat' obeščanie [TP5 PRO prijti odin/*odnomu } \\
& \text { give }_{I N F} \text { promise } \text { come }_{I N F} \text { alone }{ }_{N O M / * D A T}
\end{aligned}
$$

Although slightly awkward, (11) still only allows nominative odin. Conceptual issues involving timing and look-ahead may arise under minimalism's standard bottom-up model: imagine that odin in (11) is agreeing with its local PRO, which gets its case from the PRO of TP4, which in turn gets its case from the PRO of TP3, which gets its case from the PRO of TP2, which gets its case, at last, from Ivan in TP1. This implies that Spell-Out of the lowest clause must be delayed until the highest clause is built, an assumption that should not be compatible with phase theory unless, ${ }^{21}$ as Landau (2008) contends, the entire sentence is one domain. For him such transparent infinitivals are not bare TPs, as I have represented them, but rather TPs embedded in CPs. These CPs are, however, weak phases hence, in Landau's system, nominative can be assigned by the matrix T probe both to Ivan and to odin at the same time. Alternatively, one might follow Babby (2009) in rejecting PRO under OC. As I discuss in

\footnotetext{
21 Under Chomsky's phase theory, Spell-Out applies to the complements of certain nodes-designated phase heads, such as $v$ and $\mathrm{C}-$ much as there were designated cyclic domains in earlier generative models. For a comprehensive survey of the phase literature, see Citko (2014).
} 
Franks (2014b), elimination of PRO here makes some sense in that it allows the infinitival domain to be even smaller than TP, making case-sharing (or multiple probe) more credible. We are still left with the source of the non-agreeing dative. One could insist on a dative PRO here, assigned following Comrie's original insight by the same sort of mechanism that produces overt dative subjects with Russian infinitives. While this is by far the most common approach, in Franks (1995, 2014b, 2014c) I maintain that the dative is directly assigned to the semipredicatives, ${ }^{22}$ although whether cased PRO can (or should) be completely avoided remains unresolved. ${ }^{23}$

Secondary predication in Russian (and other languages) has also been treated in approaches to control which eschew PRO and, as I argue in Franks (2014b, 2017: section 3.1.1.1), by reducing apparent long-distance agreement to a local relationship, these may offer a more straightforward account. Most widely accepted is perhaps Hornstein's (2001) movement theory of control (MTC), which Grebenyova (2005) and Witkoś (2009 and elsewhere) apply to handle predicate adjectives in Russian and Polish, respectively. ${ }^{24}$ Under the MTC, OC reduces to A-movement. This means that the controller actually merges as the subject of the infinitive and bears its (eventual) case before moving, so that agreement (however implemented) occurs locally. Using copy and delete, one might then represent $(10 \mathrm{a})$ as follows:

$$
\begin{array}{llll}
\text { Nadja } & \text { ljubit [TP } & \text { gotovit' } & \text { sama]. } \\
\text { Nadja }_{N O M} & \text { likes } & \text { cook }_{I N F} & \text { alone }_{F . N O M}
\end{array}
$$

A more complicated sentence, such as (11), would have a series of where each PRO stands, but the idea is the same. In my own more recent work I adopt a multiattachment approach (or multidominance, as in Citko 2011 among many others), but this may well be a notational variant of the MTC. The basic idea is that there are no autonomous copies, "movement" is just the calling up of the same information from different places in the tree. Items are

\footnotetext{
22 In Franks (1995) this was done in the canonical indirect object configuration, and in Franks (2014c) dative is valued on the semipredicative by a C empowered by a [-finite] $\mathrm{T}([\mathrm{T}[-\mathrm{fin}]+\mathrm{C}])$.

23 Either way, the instrumental on ordinary adjectives needs to be explained, as well as the difference between the two classes of elements. See Madariaga (2006) and Franks (2014b) for discussion.

24 As I discuss in Franks (2014b), the question of how predicate adjectives receive their case under the MTC has been a complex and hotly debated one. However, since most of the argumentation concerns Icelandic rather than Slavic, I do not address the issues here but rather refer interested readers to the Linguistic Inquiry exchanges in Boeckx and Hornstein (2006), Bobaljik and Landau (2009), and Boeckx, Hornstein, and Nunes (2010).
} 
structured data sets with addresses, and movement is a metaphor for multiple occurrences, so that distinct nodes in the tree "point to" the same address. The information in (12) might thus be represented something like this:

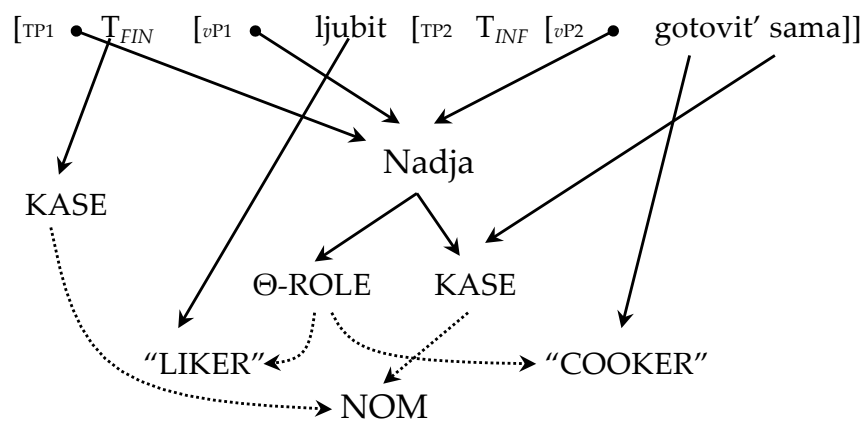

In this instantiation of feature-sharing, sama is co-valued with Nadja in that whatever case the latter eventually acquires is shared by the former; Spell-Out must wait, and the spreading of features behaves as if they were passed from the top down.

In these examples the case shared is nominative, but the phenomenon extends to other cases. In Polish, genitive (of quantification) subjects can induce genitive predicate adjectives and, in Icelandic, semipredicatives can reflect a variety of quirky cased subjects. Moreover, as pointed out by Babby (2009) and demonstrated by Landau (2008) in his judgment studies, agreement does not always fail under object control, contra (10b). Landau reports considerable variation, with $60 \%$ of speakers interviewed accepting the accusative and $90 \%$ accepting the dative in (14):

Ona poprosila ego $[$ PRO ne ezdit' tuda
she asked him hiCC $_{A C}$ not travel
INF there
odnogo/odnomu $^{\text {zavtra]. }}$
alone $_{A C C / D A T}$ tomorrow

'She asked him not to travel there alone tomorrow.'

There are clearly two competing structures and/or strategies, and, as Landau shows, sometimes only agreement/case-sharing is viable, sometimes only dative is, and sometimes both are. I think the real question is whether something deep or superficial is involved here. While I prefer to believe OC implies a bare TP whereas agreement and arbitrary control imply a CP with dative valued by $\mathrm{C}$, examples such as (14) or the following, also from Landau and again with both options, suggest that the matter may be more mechanical than profound: 


\section{(15) Ivan vstal [čtoby PRO pogovorit' sam/samomu \\ Ivan $_{N O M}$ stood-up in-order speak $_{I N F} \quad$ self $_{\text {NOM/DAT }}$ \\ s tolpoj]. \\ with crowd}

'Ivan stood up to speak to the crowd on his own.'

Here, although $93 \%$ accepted the dative, which is in keeping with the idea that ctoby 'in order' projects a CP, according to Landau $60 \%$ of speakers interviewed also accepted the nominative. While this transparency is not surprising, given the OC interpretation of (15), it does cause one to question the status of $\mathrm{CP}$ in blocking case-transmission. On the other hand, without čtoby (which I would contend implies a bare TP), agreement/case-sharing with Ivan is obligatory. It thus may be that the infinitival clauses in (14) and (15) could be smaller than CPs-with čtoby not necessarily analyzed as a $\mathrm{C}^{0}$ even if čto is-or that these CPs only optionally count in blocking agreement. In sum, important issues raised by the vicissitudes of agreement by secondary predicates in Slavic touch upon whether PRO can have case and, if so, how does it get it and what kind(s) can it get, as well as larger puzzles about the architecture of grammar, the workings of Spell-Out, and the nature of control.

\subsection{Agreement and Coordination}

A third area of emerging interest is the behavior of coordinate phrases. With their robust agreement morphology, coordinated subjects in Slavic languages have attracted considerable attention in much recent work. ${ }^{25}$ Although Slovene, with its intersecting system of three genders and three numbers (singular, dual, and plural), and BCS, with three genders cutting across singular and plural, have been the best studied, there is also important work on the more semantically-driven Polish system. ${ }^{26}$

While there is some debate about the empirical facts-experimental data are reported for Slvn in Marušič, Nevins, and Badecker (2015) and a number of the papers in Arsenijević et al. (2016) provide data for BCS-the relevant variables are fairly clear. Given a coordination of two (or more) nominal expressions, agreement expressed on the verb can vary depending on the gen-

25 Also of interest but not treated here is the fascinating problem of what happens when an adjective scopes over two conjuncts that differ in gender (and/or number). Aljović and Begović (2016) explore this question for BCS, as does Willim (2012) for Polish.

26 For broader coverage, the interested reader is referred to Corbett (2010), as well as the wide-ranging collection of articles (and references therein) that comprise JSL 24.1 (i.e., Arsenijević et al. 2016). 
ders and numbers of those expressions as well as on whether the coordinated phrase precedes or follows the verb. ${ }^{27}$ First conjunct agreement (FCA) under Verb-Subject (VS) order is a common feature of unaccusatives universally, and has long been observed for Slavic. Here is the standard paradigm, exemplified by Czech: ${ }^{28}$
a. Na rohožce seděli
[pes a kočka]. on mat were.sitting ${ }_{M . A N . P L}$ $\operatorname{dog}_{M . S G}$ and cat $_{\mathrm{F} . S \mathrm{G}}$ 'The dog and the cat were sitting on the mat.'
b. Na rohožce seděl/*seděla
[pes a kočka].
$\operatorname{dog}_{M . S G}$ and $\operatorname{cat}_{F . S G}$ on mat were.sitting ${ }_{M . S G / * F . S G}$
c. Na rohožce
seděla/*seděl
on mat
were.sitting ${ }_{F . S G / * M . S G}$
[kočka a pes].
cat $_{F . S G}$ and $\operatorname{dog}_{M . S G}$

[Czech]

The kind of "close" FCA in (16b) and (16c) can be understood either as (i) probing down and encountering the first conjunct as structurally highest, assuming a hierarchical arrangement as in (18a) or (18b) below, or as (ii) agreement under linear proximity, assuming a non-hierarchical arrangement, as in (18c). I take the form of the verb in (16a) to reflect agreement with the entire phrase, which is resolved as masculine (animate) plural by default. ${ }^{29}$ Agreement with a lower/more distant conjunct is (universally) unacceptable, something which follows from the fact that under VS order the second NP does not meet either criterion of proximity-it is neither hierarchically nor linearly closest to the verb. Excluding this possibility means that we can disregard VS order, since it tells us nothing definitive about the nature of FCA, and concentrate instead on Subject-Verb (SV) order.

Resolution of mismatches is not always straightforward, and, while one might expect coordination of likes to be uncontroversial, this is not always true. Consider the Slvn examples cited by Corbett (2010), who provides a great deal of data from a large array of Slavic languages:

\footnotetext{
27 It is not possible to do justice to all the permutations here. Marušič, Nevins, and Badecker (2015) treat no fewer than 37 different conditions, and that is in just one language and without manipulating person.

28 Badecker (2007) cites these Czech FCA examples-which he calls "partial agreement"-from Short (1993), but, so far as I am aware, the same pattern can be demonstrated with any other Slavic language.

29 In this section I put aside consideration of person and person mismatches, which add an additional level of complexity to the problem of $\phi$-feature resolution; see Citko (2004) for some relevant discussion.
} 


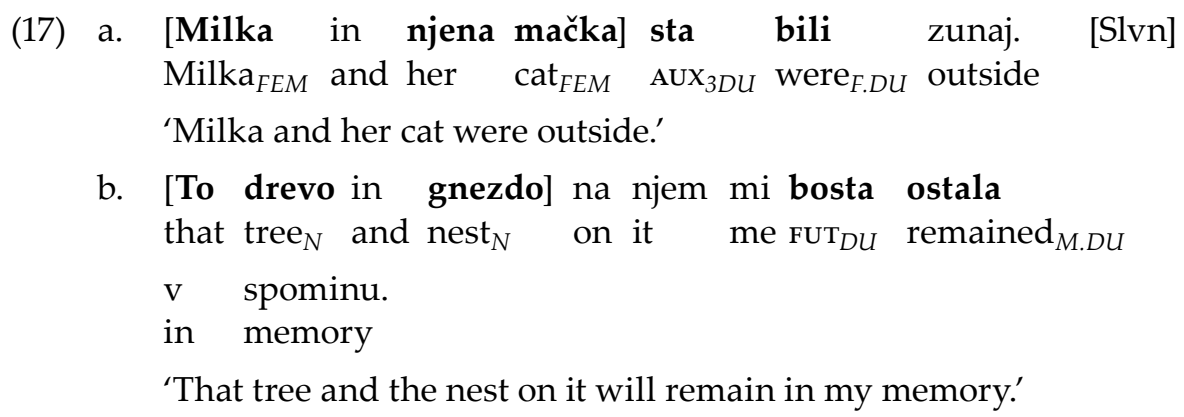

In Slvn (and BCS) coordination of feminines results in the expected feminine plural, but for some reason default masculine arises when both conjuncts are neuter, as in (17b). So one puzzle is why a neuter singular plus another neuter singular does not amount to neuter dual, even though a feminine singular plus another feminine singular does give feminine dual. This puzzle bears on the larger question of the structure of coordinated phrases, a much debated matter in the general linguistics literature. ${ }^{30}$ Taking the coordination itself to be some kind of Boolean phrase (\&P), the most commonly assumed X-bar theoretic structure is given in (18a), with the first conjunct the specifier of an \&P, although other articulations are sometimes considered, such as (18b), with the first conjunct also an \&P, as argued for in Franks and Willer-Gold (2014). In addition, especially to the extent that linear proximity can determine agreement, there remain good reasons to prefer a flat representation, as in (18c): ${ }^{31}$
a. $\left[\& P \mathrm{NP}_{1}\left[\&^{\prime}\right.\right.$ and $\left.\left.\mathrm{NP}_{2}\right]\right]$
b. $\left[\& \mathrm{P}\left[\& \mathrm{P} \& \mathrm{NP}_{1}\right]\left[\&^{\prime} \& \mathrm{NP}_{2}\right]\right]$
c. $\left[\& \mathrm{PNP} \mathrm{N}_{1} \& \mathrm{NP}_{2}\right]$

One way of viewing the problem is thus how the features of \&P are determined on the basis of those of NP1 and NP2. In Franks and Willer-Gold (2014), we implement a system of feature percolation as unification, where \& has no $\phi$-features, hence is non-distinct from both masculine and feminine, and neuter is the absence of gender features. Others, such as Bošković (2009a) or Marušič, Nevins, and Badecker (2015), restrict the computation of values of \&P to number (which is clearly necessary, since, as shown in (17), singular plus

\footnotetext{
30 See Progovac (1998a) for a comparison of structures and an early survey of the relevant literature.

31 Whether (18c) is generated as such, as argued in Franks and Willer-Gold (2014), or created in the course of the derivation through some (possibly post-syntactic) process of "flattening" binary structures, as proposed in Marušič, Nevins, and Badecker (2015), is an open issue.
} 
singular gives dual) and calculate the gender of the verbal participle "probe" in other ways. Their proposals about the auxiliary mechanism(s) needed to provide the participle with gender features are complex, and the jury is still out as to whether or not these mechanisms are motivated and, as such, will enlighten us about the processes of morphosyntax. ${ }^{32}$ They require the probe to operate independently with respect to number and gender: Marušič, Nevins, and Badecker (2015) use "Split-Probe" or ("No-Default") to probe different goals for number and gender and Bošković uses "Secondary Agree" to value gender on the target by probing twice inside $\& \mathrm{P}^{33}$ In both systems, the probe searches for matching number features, and finds its number feature on $\& \mathrm{P}$ but its gender feature on NP1 or NP2. Another difference is that whereas Marušič, Nevins, and Badecker (2015) employ flattening to induce agreement with the linearly closest conjunct (i.e., NP2), Bošković (2009a) challenges the idea that agreement can target either conjunct. Either way, I do not think that what is going on involves some kind of amalgamation of two sources of information. Consider Slvn (19), from Franks and Willer-Gold (2014), which conjoins a dual with a singular:

$$
\begin{array}{llll}
\text { a. Prišli/ }{ }^{*} \text { Prišle so } & \text { (dve) sestri in brat. } \\
\operatorname{arrived}_{M . P L / * F . P L} & \operatorname{AUX}_{P L} & \text { two sisters and brother }
\end{array}
$$

'There arrived two sisters and a brother.'
b. Prišli
sta
(dve) sestri in brat.
arrived $_{F . D U}$
$\mathrm{AUX}_{D U}$
two
sisters and brother

What (19a) shows is that the verb cannot derive plural number from \&P but feminine gender from the closest conjunct. Instead, as in (19b), if the verb probes the feminine gender of NP1 sestri, then it must also probe NP1's dual number.

To see what the possible agreement controllers are, we need also to ask what happens when NP1 and/or NP2 are themselves plural. ${ }^{34}$ Often in cases of mismatch there can be multiple possibilities, as in (20), discussed in Marušič, Nevins, and Badecker (2015):

\footnotetext{
32 For experimental findings bearing on this debate, see Arsenijević and Mitić (2016).

33 Bošković's "Secondary Agree" involves an elaborate supplementary feature valuation system triggered by the "lethal ambiguity" of valuators associated with pied-piping.
}

34 For a recent treatment of coordinate phrases with singular conjuncts in Serbian, see Despić (2016). 
(20) [Radirke in peresa] so se prodajali/a/e najbolje. [Slvn] $\operatorname{eraser}_{F . P L}$ and $\operatorname{pen}_{N . P L} \mathrm{AUX}_{P L}$ REFL sold $\mathrm{R}_{\text {M.PL/N.PL/F.PL }}$ best

'The erasers and the pens sold the best.'

This single Slvn sentence tolerates three distinct resolutions: what can be characterized as default (or \&P) agreement, last (or closest) conjunct agreement (LCA), and (distant) FCA-here, masculine, neuter, and feminine, respectively. In BCS, on the other hand, distant FCA is not possible, as discussed by Bošković (2009a) and shown by the following Croatian example from Franks and Willer-Gold (2014): ${ }^{35}$

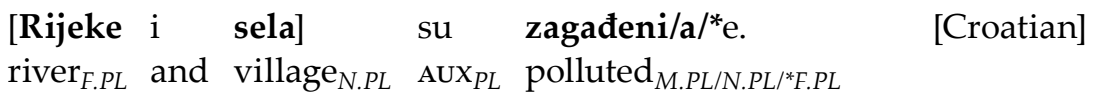

'The rivers and the villages are polluted.'

Distant FCA is vanishingly rare across the world's languages, not just in Slavic. This is a curious fact, because close FCA (i.e., under VS order) is so common. The difference between these cannot therefore just be a matter of the verb probing up rather than down, since from the perspective of $(18 \mathrm{a}) /(18 \mathrm{~b})$ NP1 should be equally accessible, as the highest target in \&P. Of course, from the perspective of (18c), which encodes linear proximity, they are completely different, but reducing FCA as in $(16 b, c)$ to linear order seems to me to be misguided. This phenomenon is cross-linguistically extremely robust-much more so than (close) LCA is-plus it has the specific hallmarks of an existential construction, such as unaccusativity and a fronted locative (or expletive there). But invoking height for agreement when looking down the tree leaves the (marked, but very real) option of agreement with radirke 'erasers' in Slvn (20) unexplained. In sum, agreement with coordinate subjects in Slavic presents a variety of problems and has led to a range of proposals in the literature. Solving the puzzles of mismatch, feature resolution, and competing controllers should tell us more about the structures of coordination and the mechanics of agreement in general.

35 I refer to the language in (21) as Croatian (rather than BCS) in keeping with my coauthor's preference. Bošković (2009a), which inspired renewed interest among generativists in these agreement phenomena, uses the traditional Yugoslav term Serbo-Croatian, which I conventionalize as BCS. In this vein, it should be noted that a telling conclusion to be drawn from the extensive regional surveys conducted by Willer-Gold et al. (2016) is that there really are no measureable differences with respect to predicate agreement with coordinate subjects across the entire BCS terrain. 


\subsection{Nominal Structure and Phases}

Here I describe two noteworthy aspects to the contributions to generative syntax of studying the structure of Slavic nominal phrases. ${ }^{36}$ One concerns how clitics fit into the various extended projections of NP, and the other concerns how these projections function as syntactic domains. These aspects are not necessarily unified, so I postpone consideration of clitics until section 4.1. This section reviews the nature and status of NP projections, an area in which, I believe, significant advances have been made based on Slavic data.

One fundamental debate has been over whether or not there are DPs in languages which lack overt determiners, which means-with a few credible exceptions-all the Slavic languages except Macedonian and Bulgarian. ${ }^{37} \mathrm{An}$ important early paper arguing for DP in BCS is Progovac (1998b), an idea challenged by Bošković (2005) on the basis of left-branch extraction data. Compare two of his Mac and BCS examples: ${ }^{38}$

a. *Kakva ${ }_{i}$ prodade Petko [ $t_{\mathrm{i}}$ kola]?

[Mac]

what-kind sold Petko car

'What kind of car did Petko sell?'

[cf. Kakva kola ${ }_{i}$ prodade Petko $t_{\mathrm{i}}$ ?]

b. ${ }^{*}$Novata $_{i}$ ja prodade Petko [ $t_{i}$ kola $]$. new $_{D E F}$ HER $_{O B J}$ sold Petko car

'Petko sold the new car.'

[cf. Novata kola $a_{i}$ ja prodade Petko $t_{\mathrm{i}}$ ?]

(23)

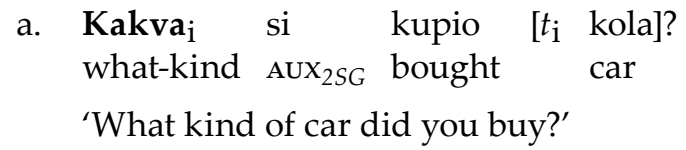

$[\mathrm{BCS}]$

36 For a more general discussion of Slavic nominal phrases, see Rappaport (2010).

37 There is too much relevant literature to cite here, but for an excellent overview of the Slavic debate and a comprehensive bibliography, see Pereltsvaig (2013). Although not limited to Slavic, the papers in Schürcks, Giannakidou, and Etxeberria (2014) are also a useful recent resource.

Like $\mathrm{Bg}$, Mac inflects the highest head in the nominal projection for definiteness (with, unlike $\mathrm{Bg}$, a [ \pm proximate, \pm distant] contrast). Like $\mathrm{Bg}$, Mac has an impoverished case system, reflected in the gloss "objective" on the clitic ja; unlike in Bg, however, definite objects are obligatorily doubled. See Franks (2015c) for a comparison of DP-structure in Mac and Bg. 


\section{(23) b. Lijepe ${ }_{i}$ je vidio [ $t_{\mathrm{i}}$ kuće]. beautiful $\mathrm{AUX}_{3 S G}$ saw houses}

'He saw houses which were beautiful.'

The observation that the viability of LBE correlates with the absence of articles is an old one, going back at least to Corver (1990), and couching this within the DP vs. NP contrast is an obvious move. Bošković (2005) argues that the bracketed phrases are DPs in Mac (22), but NPs in BCS (23). In a series of subsequent papers, beginning with Bošković (2008), he describes and attempts to derive many other correlations, essentially positing a DP/NP parameter with extensive empirical coverage. ${ }^{39}$ The true situation is surely more complex than this, with additional projections possible, as in Pereltsvaig (2006), and some languages exhibiting mixed behavior, perhaps because of changes in progress, as I suggest for Slvn in Franks (2013). ${ }^{40}$ But if there is indeed a fundamental typological difference among languages depending on whether or not the nominal domain includes a dedicated DP projection, that would turn out to be a major theoretical conclusion with a Slavic impetus.

It seems to me that one way to look at this (and other) variation in phrase structure is in terms of whether particular features project their own phrases or not. So one might well imagine that, in Bg or Mac, features expressing definiteness and specificity project their own, dedicated, DP, whereas in Rus-

39 Here is the list of ten differences from Bošković (2008), as summarized in Despić (2013):

i. "Left-branch extraction" is possible only in languages without articles.

ii. "Adjunct extraction" is possible only in languages without articles.

iii. (Japanese-style) scrambling is possible only in languages without articles.

iv. Languages without articles disallow negative raising (i.e., strict negative polarity item licensing under negative raising), and languages with articles allow it.

v. Multiple wh-fronting languages without articles do not show superiority effects.

vi. Clitic doubling is possible only in languages with articles.

vii. Languages without articles do not allow transitive nominals with two genitives.

viii. The majority superlative reading is possible only in languages with articles.

ix. Head-internal relative clauses are island-sensitive in languages without articles, but not in those with articles.

x. Polysynthetic languages do not have articles.

Additional correlations have since been proposed by Bošković and his colleagues.

40 Although Bošković (2009b) decides that Slvn is an NP language, he does not "rule out the possibility that we are starting to witness a change here, i.e., the beginning of the emergence of a DP system" (71). 
sian and BCS they do not. A conceptual precursor to this idea can be found in much earlier work within generative grammar on quantified phrases in Slavic, beginning with Pesetsky's 1982 MIT dissertation. He showed that a simple Russian phrase such as šest' studentov 'six students', in which the NP studentov appears to receive genitive case from the quantifier šest', could be analyzed either as an NP or a QP, depending on its syntactic and semantic properties. In Franks (1995 and elsewhere) I recast this idea in terms of a DP vs. QP parameter and extended the account to accommodate other Slavic languages (especially BCS and Polish). ${ }^{41}$ Other scholars, such as Pereltsvaig (2006), have revisited this problem, placing the numeral phrase facts into the larger context of allowing different sized nominal projections in different environments. Given that the Slavic numeral phrase has been much treated elsewhere, I do not include examination of the details and variants in this survey. This is not to understate how common discussions of numeral phrases (as well as the genitive of negation) in Russian are in the general linguistic literature, but rather to emphasize that what ought to be taken from these discussions is that there are nominal projections of different sizes.

It is, in fact, this last conclusion that has turned out to be of particular theoretical significance for minimalist phase theory. Bošković $(2014,2016)$, largely on the basis of BCS data, shows that, rather than positing fixed phase heads, it is instead only the highest phrase in the extended projection of a lexical category which counts as a phase. This relativized conception of phasehood means that processes which target phases and their complements or which require the exploitation of phase edges, such as ellipsis, movement, and binding, are sensitive to what phrases project in any given nominal domain. This turns out to be an extremely powerful and promising idea, since it means not only that languages will differ in terms of whether or not a DP is projected above NP, but that there can be variation even within a single language. This variation depends on two factors: (i) what phrase(s), if any, are above NP and (ii) precisely where material at the left-edge of those phrases is situated. In BCS, it is argued, adjectival material is adjoined to NP, hence it can extract, as we saw in (23), but it also c-commands out of NP, giving rise to disjoint reference effects in the following examples from Despić (2011, 2013):

a. *[NP Kusturicin ${ }_{\mathrm{i}}$ [NP najnoviji film]] ga $_{\mathrm{i}}$ je [BCS] Kusturica's latest movie HIM $\mathrm{AUX}_{3 S G}$

zaista razočarao. really disappointed 'Kusturica, ${ }_{i}$ ' latest movie really disappointed him $_{\mathrm{i}}$ '

$\overline{41}$ For a summary of my own perspective, the reader is referred to Franks (2009a). 
(24) b. *[NP Njegovi [NP najnoviji film]] je zaista his latest movie $\mathrm{AUX}_{3 S G}$ really

razočarao Kusturicu . $_{\text {. }}$

disappointed Kusturica

'His latest movie really disappointed Kusturica.'.

Despić argues that if the structure is one of NP-adjunction, not only will Binding Principle B and C effects arise when the pronoun or R-expression is at the left-edge as in (24), but they will also arise even when ostensibly protected by another modifier, such as the demonstrative ovaj 'this': this Kusturica's latest movie HIM AUX $_{3 S G}$
a. *[NP Ovaj [NP Kusturicin ${ }_{\mathrm{i}}$ [NP najnoviji film]] $\mathbf{g a}_{\mathrm{i}}$ je
zaista razočarao.
really disappointed
'This latest movie of Kusturica,'s really disappointed himi.'
b. ${ }^{*}[\mathrm{NP}$ Ovaj [NP njegovi [NP najnoviji film]] je zaista this his latest movie $\mathrm{AUX}_{3 S G}$ really
razočarao Kusturicu . $_{\text {. }}$
disappointed Kusturica
'This latest movie of his $\mathrm{i}_{\mathrm{i}}$ really disappointed Kusturica $\mathrm{i}^{.}$

Interestingly, if the element to the left of the offending expression is a QP-projecting quantifier, such as pet 'five' or mnogo 'many', then the disjoint reference effect disappears. Here is an example from Bošković (2014), who builds on Despić's insights: ${ }^{42}$

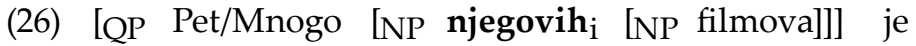 \\ five/many his $\operatorname{movies}_{G E N} \operatorname{AUX}_{3 S G}$ \\ proslavilo Kusturicu . $_{\text {. }}$ \\ made-famous Kusturica \\ 'Five/Many of his i movies made Kusturica $a_{i}$ famous.'
}

\footnotetext{
42 The QP argument was first made in Despić's 2011 dissertation but for some reason is not included in the 2013 article. For critical discussion of extending Despićs account to Mac and Bg, see LaTerza (2016), who claims that Mac and Bg-although they are DP rather than NP languages-show the same binding behavior as BCS. My informal inquiries, however, suggest problems with LaTerza's data, with closer examination revealing Mac and Bg actually to display DP language behavior, as Despić would predict. (Russian also works like BCS, but, as an NP language in Bošković's typology, this is to be expected; cf. Zanon (2015a) for extensions to Russian.)
} 
Njegov(ih) 'his' c-commands out of NP in (25b) but not in (26), hence only in the latter can it be coreferential with Kusturicu without violating Principle C.

By the same token, as Bošković (2016) shows, only elements at the phase edge can extract. He contrasts (27a) with (27b), where mladog 'young' must scope over hence start out higher than krilnog 'wing':

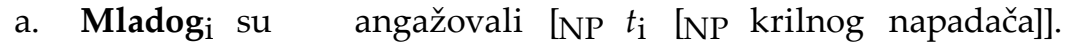 young $\mathrm{AUX}_{3 P L}$ hired wing striker
'They hired a young wing striker.'
b. *Krilnog su angažovali [NP mladog [NP $t_{\mathrm{i}}$ napadača]].

On the other hand, to the extent that adjective order is flexible, so is extraction. LBE thus amounts to extraction of the highest left branch. Lastly, an anaphor can only be bound at the edge of its phase: ${ }^{43}$
a. Marija je prodala [NP svoju [NP omiljenu knjigu]]. Marija $\mathrm{AUX}_{3 S G}$ sold her favorite book
'Marija sold her favorite book.'
b. *Marija je prodala [NP omiljenu [NP svoju knjigu]].

In his system only the outermost, adjoined position counts as the phasal edge, hence (28a) but not (28b) is acceptable. Facts such as these are of course only representative, and as Bošković, Despić, Zanon, and others have shown, the relativistic approach to phases and their edges has great potential and predictive value. In sum, a consideration of Slavic data has led to a much deeper understanding of phrase structure.

\section{What Next?}

In section 3 we considered four productive areas in which significant advances have been made on the basis of Slavic facts. In this final section, I describe three areas which I believe are likely to be productive in the next decade. None of these areas are new-indeed, identifying a new area for research in such an old field as Slavic linguistics strikes me as virtually impossible, but they are all areas which deserve closer scrutiny.

\footnotetext{
43 Bošković (2016) attributes this observation to Zanon (2015b). She assimilates Bošković's model of phase edges to various potentially problematic constructions in Russian. Because these involve quantifiers, Zanon's solutions exploit Quantifier Raising, which resolves the problems by manipulating the phase edge.
} 


\subsection{Clitics}

Despite the enormous energy devoted to the study of Slavic clitics by practitioners of generative syntax, there is little consensus about their analyis. And perhaps because I have worked so much on these myself, ${ }^{44}$ I see more questions than answers in the clitic literature. Some of these are described below.

One of my favorite mysteries is the relationship between second position (2P) and verb-adjacent (VA) clitics. Languages can develop from one system to the other (and even back again, as Pancheva 2005 shows), and there are clear $2 \mathrm{P}$ effects in VA Mac and Bg. What kind of analysis is flexible enough to vary between them ${ }^{45}$ Related to this is the issue of why clitics move in the first place. ${ }^{46}$ Given that, as shown by Bošković (2001), even within a single language they do not always move to the same position, the driving force cannot be Attract. Rather, movement must be motivated by some kind of deficiency in the clitic, but the nature of that deficiency is not yet understood-even though, as I argue in Franks (2015c), clitics are literally defined by their deficiencies.

Another major mystery concerns the internal structure of nominal projections that can themselves contain clitics, especially as seen in Bg. If Slavic clitics are $\mathrm{K}$ heads, we might want to say that KP immediately dominates NP in BCS but that there is an intervening DP in Bg:

(29)

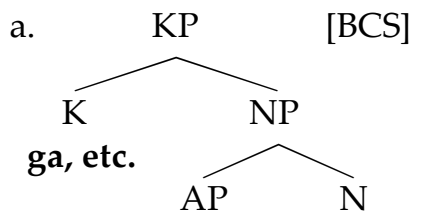

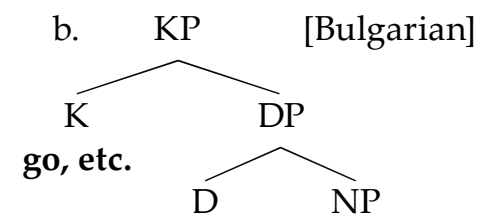

But $\mathrm{Bg}$ also allows oblique (i.e., historically dative) clitics KP-internally. As in some other Slavic languages, these can be possessives, but they can also play an argumental role in nominalizations. Here is an example from Tasseva-Kurktchieva (2004):

\footnotetext{
${ }^{44}$ Representative works are the theoretically-oriented surveys in Franks (2009b, 2010, 2016), as well as chapters 4 and 5 of Franks (2017).

${ }^{45}$ In my work I have suggested letting $2 \mathrm{P}$ be parasitic on VA, with the supporting verb itself deleted after taking the clitics to the highest head position in the clause.

${ }^{46}$ It does nonetheless seem that they cannot remain in situ. Abels (2003) exploits the idea that clitics necessarily move to explain why they cannot serve as complements to prepositions, to the extent that these do not admit stranding (i.e., the clitic must move but there is no escape from a PP).
} 


\section{(30) Ivanovoto mi izpitvane Ivan's $s_{D E F} \quad \mathrm{I}_{O B L}$ examination \\ 'Ivan's examination of me'}

I discuss these in Franks (2001, 2010, 2015c), showing that the clitic can only correspond to the highest argument of the deverbal $\mathrm{N}$ and, in the most recent paper, positing a case-licensing AgrP between KP and DP in Bg. But this begs the questions of why the case realized must be oblique and, more importantly, what is special about $\mathrm{Bg}$ (vs. all other Slavic languages, including Mac) that leads it to countenance an AgrP in the nominal domain.

Many other clitic puzzles remain. For example: When are clitics heads and when are they phrasal and how can we discriminate between these alternatives? How should apparent directionality restrictions (in seeking prosodic support) be implemented? What determines the relative order of clitics and why is this order more fixed in some languages than in others? Do auxiliary and pronominal clitics require different analyses? Why is the reflexive clitic special? How (and why) do clitics cluster and when (and why) can they sometimes be split? The list goes on and on, so my prediction is that, despite the copious body of existing research on Slavic clitics, there is still much work ahead of us.

\subsection{Clause Structure}

As with the nominal domain, there are two conflicting views of clause structure in the generative literature. One view, perhaps the dominant one, is that the grammars of all languages share a common structure so that the same categories project cross-linguistically, even if there is no overt evidence for those projections. This rigid universalist view is probably best associated with the work of Rizzi, stemming from Rizzi (1997). An alternative, which I subscribe to, claims that grammars vary in whether or not some subset of features gives rise to an independent projection. There are different ways to instantiate this idea, but the basic insight is one of Occam's razor as embodied for example in the "Minimal Structure Principle" of Bošković (1997). ${ }^{47}$ So just as there is a DP in Bg (29b) but not in BCS (29a), and there is a KP in BCS but not in Russian (since it lacks pronominal clitics), so do clauses also vary. Russian nominal expressions obviously have case, it is just that case is not realized as a separate head, and BCS and Russian nominal expressions similarly have definiteness/

\footnotetext{
47 Bošković's (1997: 25) actual statement of the MSP went as follows: "Provided that lexical requirements of relevant elements are satisfied, if two representations have the same lexical structure and serve the same function, then the representation that has fewer projections is to be chosen as the syntactic representation serving that function."
} 
specificity features, they are just reflected in ways other than morphology, especially using word order.

Turning to clauses, consider for example East Slavic, in which tense and agreement seem to be in complementary distribution: ${ }^{48}$
a. My pročyta(j)-1-y cju cikavu knyhu.
we read-PAST-PL this interesting book
'We read this interesting book.'
b. My čytaj-emo cju cikavu knyhu. we read-1PL this interesting book
'We are reading this interesting book.'

Ukrainian can only realize (past) tense $-l-$, as in (31a), or first plural agreement, as in (31b), but not both in the same clause. ${ }^{49}$ Compare this with its West Slavic neighbor Polish, in which both can be independently realized in the past:

$$
\begin{array}{llll}
\text { Przeczyta(j)-1-i-śmy tę ciekawą książkę. } & \text { tea } \\
\text { read-PAST-PL-1PL } & \text { this interesting book }
\end{array}
$$

It may thus be that there are independent AgrP and TP projections in West (and South) Slavic, whereas in East Slavic there is only a single projection (modulo the remarks in footnote 48), so that tense and agreement sometimes compete for the same head position. One might then examine the tense-aspect-mood-evidentiality (TAME) systems of the different languages, where, as made evident in Rivero and Slavkov (2014), the complexities of South Slavic $\mathrm{Bg}$ (and Mac, although they somehow avoid discussing this language) surely require far more clause-internal structure than do either East or West Slavic.

Any analysis of the provenance and locus of clausal clitics will also impact upon one's eventual clause structure. In my work I have employed AgrP for the $\mathrm{K}$ clitics, but there are newer alternatives, and other functional pro-

\footnotetext{
48 While true of the past tense, the future raises complexities. For Russian and Belarusian, I would analyze future interpretation as parasitic on perfective aspect (and, for the imperfective future, treating conjugated forms of auxiliary byt'/byc' 'to be' as formally perfective). An anonymous reviewer points out, however, that Ukr, unlike Rus and BR, also has a simple imperfective future conjugated by adding the endings -mu, -meš, -me, -memo, -mete, -mut' directly to the infinitive (alongside the Rus/BR-style conjugated auxiliary $b u d u$, etc.). One might therefore take this $-m$ - as a future marker co-occurring with agreement.

49 I take the $-y$ plural marker to be a nominal ending on the participle, in agreement with the plural subject $m y$ 'we', rather than a reflex of clausal agreement per se. Predication requires matching in gender-number, which must be kept separate from the person-number agreement imposed by AgrP.
} 
jections are surely needed for reflexive and auxiliary clitics, especially given the fact that different languages treat these differently. One interesting fact concerns the relative position of negation and auxiliary clitics. Rivero (1991), for example, drew attention to the following contrast between BCS and Slk:

a. Ni- sam čitao knjigu.

NEG AUX $_{1 S G}$ read book

$[\mathrm{BCS}]$

'I didn't read a book.'

[cf. *Ne/Ni-čitao sam knjigu.]

b. Ne- napísal som list.

NEG wrote $\mathrm{AUX}_{1 S G}$ letter

[Slk]

'I did not write a letter.'

[cf. *Nesom napísal list.]

In BCS (and Slvn) negation is prefixal on the verbal auxiliary, whereas in Slk (and Cz) it attaches to the verb itself, ${ }^{50}$ although all are prima facie $2 \mathrm{P}$ clitic languages. ${ }^{51}$ Does this warrant a different position in clause structure for negation with respect to tense in different languages, as Rivero argues, or should the data be handled in some other way, perhaps by varying the locus of the ne element (e.g., in $\mathrm{Neg}^{0}$ or SpecNegP)? Resolving these and other issues should have consequences for any comprehensive treatment of comparative Slavic clause structure.

Lastly, at the left-periphery of the clause, as noted in section 3.1 above, there are obvious differences between the positions different kinds of information-such as wh-phrases, foci, and topics-occupy in the different languages. While there has been a good deal of work trying to pin down the projections needed for a particular Slavic language ${ }^{52}$ my sense is that these, first of all, do not in general aim to respect the spirit of the MSP (i.e., they proliferate entities), and secondly, most do not seek to uncover differences in clause structure among the languages (let alone approach those differences in an explanatory fashion). ${ }^{53}$ Comparison of clausal structures across the Slavic

\footnotetext{
50 Negation directly precedes the copula, however, e.g., nesom '(I) am not'.

$51 \mathrm{VA} \mathrm{Bg}$ and Mac are superficially similar in that negation is proclitic on the verbal complex, which (since these attach to the verb) includes auxiliary and pronominal clitics.

52 For example, Arnaudova (2003), Lambova (2003), or Rivero (2005) for Bg, Bailyn (2012) for Rus, and Progovac (2005) for Serbian.

53 Notable exceptions include Migdalski and Tomić, e.g., Migdalski (2006) or Tomić (1996), although their work is largely concerned with variation in clitic systems. In a number of papers, Rivero compares phenonema across Slavic (and beyond) -in Rivero
} 
languages thus seems to me to be a potentially very productive area for future research.

\subsection{Microvariation and Speaker Strategies}

Much of what has been drawn attention to in this survey article highlights the fact that, although (genetically) closely-related, the syntactic systems of the Slavic languages can differ in striking ways. Not only that, but individual speakers can vary in their judgments and preferences in ways which may reflect register or dialect, but which may also be simply facultative. I do not think that generativists working on Slavic have paid sufficient attention to what is sometimes called "microvariation." This, alongside typological groupings that cut a broader swath, pose an analytic challenge for the next generation of Slavic syntacticians. Other, less discrete, approaches to syntax often already take variation as a point of departure. It is high time for generativists also to worry about the messiness of data and to take apparent inconsistencies more seriously. For virtually every domain I have mentioned, discrepancies in the factual basis underlying the theoretical claims are rampant. While, to be fair, these problems are increasingly acknowledged in the literature, many of us (myself included) often deign to consign them to a waffling footnote.

That being said, I do not have a panacea for this endemic problem. I do not advocate throwing out the formal baby, with its digitally defined and clearcut properties, along with the functional bathwater, with its analog jumble of intermingled qualities. But how to reconcile the two? My view is that the right way to understand variation is as a complex arrangement of discrete solutions. Hierarchies, let alone "squishes" of the type made famous for Slavic by Corbett (1978), can be reduced to competition between alternative analyses of similar material. Similarly, historical change, as described by Kroch (2001), is a matter of the child's predilection to adopt one structure over another for the same surface string. All sorts of factors affect the data and decisions, whether these be traditional grammaticality judgments or more sophisticated experimental results using response time, eye-tracking, MRI, computer simulations, and other fancy technologies. If generativists are to adhere to our discretely symbolic and mentalistically computational theory of language, it seems to me we will need to promote models of grammar which manipulate competing structures and derivations. Here, in conclusion, are three brief thoughts along those lines.

First, I think exploitation of interface properties is paramount. One way to build choice into a generative system that I have advocated in much earlier

and Slavkov (2014), for example, data from the verb systems of seven Slavic languages are cited-but their focus is primarily on morphological rather than syntactic expression of the various TAME categories in the different languages. 
work is the following: let the syntax generate structures that are in some way underdetermined (e.g., by leaving open linear order or which copies are pronounced or the position in which an element is interpreted) and let the decision among alternatives be in some way policed at the interfaces with morphophonological interpretation (PF) and semantic interpretation (LF). That way, optimality theoretic-like criteria can be brought to bear, allowing all sorts of factors to come into play.

Another source of messiness in data is failure to pay attention to how speakers are evaluating the data under investigation. It goes without saying that prosodic and functional sentence perspective information is often overlooked and that these factors can often bias different reactions. Prosody and information structure are admittedly very difficult to control for. More generally, though, interpretation is paramount. One essential aspect to any structural analysis is meaning, and-to adapt Jakobson's dictum-syntax without meaning is meaningless. In my generation, Slavic syntacticians largely eschewed serious consideration of semantics (in my case, at least, because of how hard it is). But I suspect paying careful attention to differences in meaning will shed light on apparently conflicting data. Too often, it seems to me, interpretative factors are overlooked. Here are some relevant illustrations from the literature.

To return to agreement and coordination, the topic of section 3.3 above, different judgments might sometimes correlate with differing interpretations. For example, Citko (2004) notes that FCA is impossible in Polish in what she calls plural environments:

$$
\begin{aligned}
& \text { a. Do pokoju weszli/weszła Maria i Jan. } \\
& \text { to room entered } \text { VIR.PL/F.SG Maria and Jan } \text { 'Maria and Jan walked into the room.' }
\end{aligned}
$$

b. Do pokoju razem weszli/* weszła Maria i Jan. 'Maria and Jan walked into the room together.'

Or recall the famous fact that there are two options for agreement with numerically quantified subjects in Russian:

$$
\begin{array}{lll}
\text { Šest' } & \text { studentov } & \text { prišli/prišlo. } \\
\text { six } & \text { students } & \text { GEN.PL } \\
\text { arrived }_{P L / N . S G} \\
\text { 'Six students arrived.' }
\end{array}
$$

While the plural is sometimes thought of as syntactic agreement and the neuter singular as semantic, there is more to the story. As noted in section 3.4, Pesetsky (1982) argued that either the numeral šest' 'six' or the nominal 
studentov 'students' could be the head of the expression šest' studentov. One of his most important observations was that plural agreement corresponds to an individuated reading (which he analyzed in terms of Quantifier Raising [QR]), whereas neuter singular (non)agreement corresponds to a group reading. In his account QR was impossible when the numeral was the head, something which both forced the neuter singular option and led to the group interpretation. The moral is that, if different agreement patterns reflect different derivations and/or structures, and these in turn correspond to different meanings, then failure to control for subtleties of meaning can introduce unnecessarily messy data.

Or consider the well-known distinction between single-pair and pair-list interpretations for multiply fronted wh-phrases. Although not mentioned in section 3.1, it often turns out that when alternative morphosyntactic instantiations exist, these correspond to different interpretative possibilities. Thus, Rudin (2009: 411-17) describes how in Bg correlatives, which are formed from $w h$-words plus the suffix -to, the ordinarily obligatory suffix is optional on the first $w h$-word when there is more than one $w h$-word:

a. Koj kakvoto iska, da vzeme.
who what-To want $_{3 S G}$ to take $3 S G$

'Let everyone take what they want.'

b. Kojto kakvoto iska, da vzeme. who-тo what-тo want $_{3 S G}$ to take $3 S G$

'Whoever wants whatever, let them take it'

While the meanings are so close that one is tempted just to treat the first -to as freely droppable, Rudin observes that there is a subtle semantic difference: having a repeated -to correlates with the single-pair interpretation, whereas a single -to scoping over both $w h$-words implies the pair-list reading. This presumably depends on how high the -to (or the operator it expresses) is attached. Rudin's (2009: 413) conclusion is that "the (a) versions have the wh-words in SpecCP, while the (b) versions do not." She also explores the fact that, unlike multiple correlatives, multiple free relatives in Bg require a single -to at the end, explaining it in terms of the impossibility of a single-pair reading.
a. Vzemajte koj kakvoto može. take $_{I M P}$ who what-To $\operatorname{can}_{3 S G}$
'Let everyone take what they want.'
b. *Vzemajte kojto kakvoto može. 
In Rudin's (2009: 415) account, the multiple free relative construction differs from the multiple correlative construction in being "possible only in languages which place at least one wh-word in SpecCP," so that "both wh-words are in a Spec-head relation with a single $\mathrm{C}^{0}$, resulting in a surface appearance of -to suffixed only to the last $w h$-word." Interpretation thus not only correlates with apparent morphological quirks but serves as a valuable clue to syntactic structure.

Sometimes interpretative options can be indicative of distinct syntactic structures even when there is no morphological contrast. Bošković (2002: 358-359) for example observes that the question in BCS (38) can accommodate either a pair-list or a single-pair answer:

$$
\begin{aligned}
& \text { Ko je šta kupio? } \\
& \text { who AUX }{ }_{3 S G} \text { what bought } \\
& \text { 'Who bought what?' }
\end{aligned}
$$

In his analysis, the single-pair reading is incompatible with (overt) wh-movement to SpecCP, hence such movement is optional in BCS and, according to Bošković, depends on whether $\mathrm{C}$ has been inserted in the overt syntax or only in LF. One might therefore take the viability of both pair-list or single-pair answers in (38) as indicative of competing structures, one with a CP projection and one without. ${ }^{54}$ In this way, the single-pair possibility in (38) can serve as a semantic hint that some kind of wh-in-situ analysis should be sought.

Finally, to return to the theme of this section, sometimes messiness has no obvious rhyme nor reason. It could simply be that multiple analyses compete, usually, in the spirit of Kroch (2001), in the course of historical change, but also, I believe, sometimes as a stable situation. Identifying the multiple analyses and coming up with heuristics to decide which analysis is appropriate when is a major but not insurmountable challenge for future syntacticians. In sum, while there is much excellent comparative work in the Slavic generative syntax canon, that work, of which Franks (1995) is representative, generally posits a straightforward choice, either couched in parametric or lexical feature terms, to discriminate the grammars of the languages under consideration. This is usually conducted with Chomsky's apocryphal "ideal" speaker-hearer in mind and, as such, tends to suppress the extent of variation. But the cost of abstracting away from raw data, in my opinion, is high. Generative syntacti-

\footnotetext{
54 Alternatively, both readings in (38) are derived from the wh-in-situ structure, a possibility seemingly necessitated by the compatibility of both pair-list and single-pair readings in incontrovertible wh-in-situ languages; for BCS, Bošković $(2002,2010)$ only states that wh-questions do not have to involve overt movement SpecCP (i.e., that C may be inserted in LF). See also Grebenyova (2012) for discussion, as well as Šimík's detailed 2014 review of her monograph.
} 
cians cannot afford to alienate our colleagues who do not share our assumptions about linguistic architecture, including representations, derivations, and the mentalist underpinnings of grammar.

\section{References}

Abels, Klaus. (2003) "A note on clitics and P-stranding". Wayles Browne, JiYung Kim, Barbara Partee, and Robert Rothstein, eds. Formal approaches to Slavic linguistics: The Amherst meeting, 2002. Ann Arbor: Michigan Slavic Publications, 1-22.

Aljović, Nadira and Muamera Begović. (2016) “Morphosyntactic aspects of adjectival and verbal first-conjunct agreement". Journal of Slavic linguistics 24(1): 7-39.

Antonyuk, Svitlana. (2015) Quantifier scope and scope freezing in Russian. Ph.D. dissertation, Stony Brook University.

Arnaudova, Olga. (2003) Focus and Bulgarian clause structure. Ph.D. dissertation, University of Ottawa.

Arsenijević, Boban and Ivana Mitić. (2016) “On the number-gender (in)dependence in agreement with coordinated subjects". Journal of Slavic linguistics 24(1): 41-69.

Arsenijević, Boban, Marijana Kresić, Nedžad Leko, Andrew Nevins, and Jana Willer-Gold, eds. (2016) Agreement in Slavic. [Journal of Slavic linguistics, 24(1).]

Babby, Leonard. (1975) A transformational analysis of Russian adjectives. The Hague: Mouton.

— (1980) Existentional sentences and negation in Russian. Ann Arbor, MI: Karoma Publishers.

- (2009) The syntax of argument structure. Cambridge, UK: Cambridge University Press.

Badecker, William. (2007) "A feature principle for partial agreement". Lingua 117: 1541-65.

Bailyn, John. (2006) "Slavic generative syntax". Steven Franks et al., eds. Slavic linguistics 2000. [Glossos 8: 1-54.] Available online at: http://slaviccenters.duke. edu/projects/glossos-journal/issues/issue-8

- (2012) The syntax of Russian. New York: Cambridge University Press.

Billings, Loren and Catherine Rudin. (1996) "Optimality and superiority: A new approach to multiple-wh ordering". Jindřich Toman, ed. Formal approaches to Slavic linguistics: The College Park meeting, 1994. Ann Arbor: Michigan Slavic Publications, 35-60.

Bobaljik, Jonathan and Idan Landau. (2009) "Icelandic control is not A-movement: The case from case". Linguistic inquiry 40(1): 113-32. 
Boeckx, Cedric and Norbert Hornstein. (2006) "Control in Icelandic and theories of control". Linguistic inquiry 37(4): 591-606.

Boeckx, Cedric, Norbert Hornstein, and Jairo Nunes. (2010) "Icelandic control really is A-movement: Reply to Bobaljik and Landau". Linguistic inquiry 41(1): 111-30.

Bondaruk, Anna. (2004) PRO and control in English, Irish and Polish: A minimalist analysis. Lublin: Wydawnictwo KUL.

- (2013) Copular clauses in English and Polish: Structure, derivation, and interpretation. Lublin: Wydawnictwo KUL.

Bošković, Željko. (1997) The syntax of nonfinite complementation: An economy approach. Cambridge: The MIT Press.

_ . (1999) "On multiple feature checking: Multiple wh-fronting and multiple head movement". Samuel D. Epstein and Norbert Hornstein, eds. Working minimalism. MIT Press: Cambridge, Mass, 159-87.

. (2001) On the nature of the syntax-phonology interface. Amsterdam: Elsevier.

- (2002) "On multiple wh-fronting". Linguistic inquiry 33(3): 351-83.

. (2005) "On the locality of left branch extraction and the structure of NP". Studia linguistica 59(1): 1-45.

. (2008) "What will you have, DP or NP?" Emily Elfner and Martin Walkow, eds. Proceedings of the 37th Meeting of the North East Linguistic Society, University of Illinois, Urbana-Champaign, October 13-15. Amherst: University of Massachusetts, GLSA, 101-14.

- (2009a) "Unifying first- and last-conjunct agreement". Natural language and linguistic theory 27(3): 455-96.

- (2009b) "The NP/DP analysis and Slovenian". Proceeding of the University of Novi Sad Workshop on Generative Syntax 1, 53-73.

- (2010) "Wh-phrases and wh-movement in Slavic". Steven Franks, ed. Contemporary issues in Slavic linguistics. [Glossos 10: 1-45.] Available online at: http://slaviccenters.duke.edu/projects/glossos-journal/issues/issue-10

- (2014) "Now I'm a phase, now I'm not a phase: On the variability of phases with extraction and ellipsis". Linguistic inquiry 45(1): 27-89.

- (2016) "Getting really edgy: On the edge of the edge". Linguistic inquiry 47(1): 1-33.

Brecht Richard and Catherine Chvany, eds. (1974) Slavic transformational syntax. Ann Arbor: Michigan Slavic Materials.

Brown, Sue Ellen (1996) The syntax of negation in Russian. Ph.D. dissertation, Indiana University.

Chidambaram, Vrinda. (2013) On resumptive pronouns in Slavic. Ph.D. dissertation, Princeton University.

Chvany, Catherine. (1975) BE-sentences in Russian. Columbus, Ohio: Slavica.

Chvany, Catherine and Richard Brecht, eds. (1980) Morphosyntax in Slavic. Columbus, Ohio: Slavica. 
Citko, Barbara. (2000) Parallel merge and the syntax of free relatives. Ph.D. dissertation, Stony Brook University.

. (2004) "Agreement asymmetries in coordinate structures". Olga Arnaudova, Wayles Browne, Maria Luisa Rivero, and Danijela Stojanović, eds. Formal approaches to Slavic linguistics: The Ottawa meeting 2003. Ann Arbor: Michigan Slavic Publications, 91-107.

Citko, Barbara. (2011) Symmetry in syntax: Merge, move, and labels. New York: Cambridge University Press.

- (2014) Phase theory: An introduction. New York: Cambridge University Press.

Comrie, Bernard. (1974) "The second dative: A transformational approach". Richard Brecht and Catherine Chvany, eds. Slavic transformational syntax. Ann Arbor: Michigan Slavic Materials, 123-50.

Corbett, Greville. (1978) "Numerous squishes and squishy numerals in Slavonic". International review of Slavic linguistics 3: 43-73.

- (2010) "Agreement in Slavic". Steven Franks, ed. Contemporary issues in Slavic linguistics. [Glossos 10: 1-61.] Available online at: http://slaviccenters. duke.edu/projects/glossos-journal/issues/issue-10

Corver, Norbert. (1990) The syntax of left branch extractions. Ph.D. dissertation, Tilburg University.

Despić, Miloje. (2011) Syntax in the absence of determiner phrase. Ph.D. dissertation, University of Connecticut.

. (2013) "Binding and the structure of NP in Serbo-Croatian". Linguistic inquiry 44(2): 239-70.

- (2016) "Coordinating gender: What can coordinate structure agreement tell us about gender?" Studies in Polish linguistics 11(1): 1-25.

Dukova-Zheleva, Galina. (2010) Questions and focus in Bulgarian. Ph.D. dissertation, University of Ottawa.

Dyakonova, Marina. (2005) "Russian double object constructions". Amsterdam Center for Language and Communication working papers 2(1): 3-30.

Franks, Steven. (1995) Parameters of Slavic morphosyntax. Oxford: Oxford University Press.

\section{$1-7$.}

. (1996) "Reflections: Building bridges". Journal of Slavic linguistics 4(1):

. (1999) "A copy and delete analysis of second position clitics". Zeitschrift für Slawistik 44(2): 155-66.

. (2001) "The internal structure of Slavic NPs, with special reference to Bulgarian". Adam Przepiórkowski and Piotr Bański, eds. Generative linguistics in Poland: Syntax and morphosyntax; Proceedings of the GLiP-2 Conference held in Warsaw, Poland, 9-10 December 2000. Warszawa : Instytut podstaw informatyki PAN, 53-69 
Franks, Steven. (2005) "Slavic languages". Guglielmo Cinque and Richard Kayne, eds. Handbook of comparative syntax. Oxford: Oxford University Press, 373-419.

. (2009a) "Case assignment in quantified phrases". Tilman Berger, Karl Gutschmidt, Sebastian Kempgen, and Peter Kosta, eds. HSK Slavische Sprachen: An international handbook of their structure, their history and their investigation. Berlin: Mouton de Gruyter, 355-69. [Handbooks of linguistics and communication science (HSK) 32/1.]

. (2009b) Clitics in Slavic. Tilman Berger, Karl Gutschmidt, Sebastian Kempgen, and Peter Kosta, eds. HSK Slavische Sprachen: An international handbook of their structure, their history and their investigation. Berlin: Mouton de Gruyter, 725-38.

- (2010) "Clitics in Slavic". Steven Franks, ed. Contemporary issues in Slavic linguistics. [Glossos 10: 1-157.] Available online at: http://slaviccenters. duke.edu/projects/glossos-journal/issues/issue-10

. (2013) "Orphans, coordination, doubling, phases: On the rise of DP in Slovenian". Slovenski jezik-Slovene linguistic studies 9, 55-92. Available online at: http://hdl.handle.net/1808/11431

- (2014a) "Multiattachment syntax, 'movement' effects, and spell-out". Peter Kosta, Steven Franks, Teodora Radeva-Bork, and Lilia Schürcks, eds. Minimalism and beyond: Radicalizing the interfaces. Amsterdam: John Benjamins, 195-235.

- (2014b) "The overgeneration problem and the case of semipredicatives in Russian". Anna Bondaruk, Gréte Dalmi, and Alexander Grosu, eds. Advances in the syntax of DPs. Structure, agreement, and case. Amsterdam: John Benjamins, 13-59.

- (2014c) "Cased PRO: From GB to minimalism and back again". Sylwester Jaworski and Jacek Witkoś, eds. New insights into Slavic linguistics. Frankfurt: Peter Lang, 73-90.

- (2015a) "Reflections: The Slavic Linguistics Society comes of age". Journal of Slavic linguistics 23(2): 189-96.

- (2015b) "Lessons for linguists from Slavists and their languages". Paper presented at the Tenth Annual Meeting of the Slavic Linguistics Society, 4 September, Heidelberg.

. (2015c) "Speculations on DP-structure: Macedonian versus Bulgarian". Małgorzata Szajbel-Keck, Roslyn Burns, and Darya Kavitskaya, eds. Formal approaches to Slavic linguistics: The first Berkeley meeting 2014. Ann Arbor: Michigan Slavic Publications, 56-76.

- (2016) "Clitics are/become minimal(ist)". Franc Marušič and Rok Žaucer, eds. Formal studies in Slovenian syntax: In honor of Janez Orešnik. Amsterdam: John Benjamins, 91-128.

- (2017) Syntax and spell-out in Slavic. Bloomington, IN: Slavica. 
Franks, Steven and Tracy Holloway King. (2000) A handbook of Slavic clitics. Oxford: Oxford University Press.

Franks, Steven and Jana Willer-Gold. (2014) "Agreement strategies with conjoined subjects in Croatian". Sylwester Jaworski and Jacek Witkoś, eds. New insights into Slavic linguistics. Frankfurt: Peter Lang, 91-113.

Harves, Stephanie. (2001) Unaccusative syntax in Russian. Ph.D. dissertation, Princeton University.

Gračanin-Yuksek, Martina. (2007) About sharing. Ph.D. dissertation, Massachusetts Institute of Technology.

Grebenyova, Lydia. (2012) Syntax, semantics and acquisition of multiple interrogatives. Amsterdam: John Benjamins.

Kim, Bora. (2010) Non-finite complements in Russian, Serbian/Croatian, and Macedonian. Ph.D. dissertation, Indiana University.

Koeva, Svetla and Ilijana Krâpova (2013) Novi izsledovanija po generativen sintaksis na bâlgarskija ezik. Sofia: Akademično izdatelstvo "Prof. Marin Drinov".

Krapova, Iliyana and Guglielmo Cinque. (2008) "On the order of wh-phrases in Bulgarian multiple wh-fronting". Gerhild Zybatow et al., eds. Formal description of Slavic languages: The fifth conference, Leipzig 2003. Frankfurt: Peter Lang, 318-336.

Kroch, Anthony. (2001) "Syntactic change". Mark Baltin and Chris Collins, eds. The handbook of contemporary syntactic theory. Malden, MA: Blackwell, 699-729.

Kučerová, Ivona. (2007) The syntax of givenness. Ph.D. dissertation, Massachusetts Institute of Technology.

Lambova, Mariana. (2003) On information structure and clausal architecture: Evidence from Bulgarian. Ph.D. dissertation, University of Connecticut.

Landau, Idan. (2008) "Two routes of control: Evidence from case transmission in Russian". Natural language and linguistic theory 26(4): 877-924.

LaTerza, Ivana. (2014) The DP category and Serbian nominal structure. Ph.D. dissertation, Stony Brook University.

- (2016) "Binding in English and South Slavic and the parameterized DP hypothesis". Linguistic inquiry 47(4): 741-53

Lavine, James. (2000) Topics in the syntax of nonagreeing predicates in Slavic. Ph.D. dissertation, Princeton University.

Lindseth, Martina. (1996) Null-subject properties of Slavic languages, with special reference to Russian, Czech, and Sorbian. Ph.D. dissertation, Indiana University.

Madariaga, Nerea. (2006) "Why Russian semipredicative items always agree". Journal of Slavic linguistics 14(1): 45-78.

Marušič, Franc. (2005) On non-simultaneous phases. Ph.D. dissertation, Stony Brook University.

Marušič, Franc, Andrew Nevins, and Bill Badecker. (2015) "The grammars of conjunction agreement in Slovenian". Syntax 18(1): 39-77. 
Medova, Lucie. (2009) Reflexive clitics in Slavic and Romance languages. A comparative view from an antipassive perspective. Ph.D. dissertation, Princeton University.

Migdalski, Krzystof. (2006) The syntax of compound tenses in Slavic. Ph.D. dissertation, LOT: Netherlands Graduate School of Linguistics.

Nikolaeva, Liudmila. (2014) The secret life of pronouns. Ph.D. dissertation, Massachusetts Institute of Technology.

Pancheva, Roumyana. 2005. "The rise and fall of second-position clitics". Natural language and linguistic theory 23(1): 103-67.

Pereltsvaig, Asya. (2006) "Small nominals". Natural language and linguistic theory $24(2): 433-500$.

- (2007) Copular sentences in Russian: A theory of intra-clausal relations. New York: Springer.

. (2013) “Noun Phrase structure in article-less Slavic languages: DP or not DP?" Language and linguistic compass 7(3): 201-19.

Pesetsky, David. (1982) Paths and categories. Ph.D. dissertation, Massachusetts Institute of Technology.

- (2013) Russian case morphology and the syntactic categories. Cambridge, MA: MIT Press.

Progovac, Ljiljana. (1998a) "Structure for Coordination". Glot international 3(7): 3-6 (Part I). Glot international 3(8): 3-9 (Part II).

- (1998b) "Determiner phrase in a language without determiners". Journal of linguistics 34(1): 165-79.

- (2005) A syntax of Serbian: Clausal architecture. Bloomington, IN: Slavica.

Rappaport, Gilbert (2010) “The Slavic noun phrase". Steven Franks, ed. Contemporary issues in Slavic linguistics. [Glossos 10: 1-64.] Available online at: http://slaviccenters.duke.edu/projects/glossos-journal/issues/issue-10

Richards, Norvin. (2001) Movement in language: Interactions and architectures. Oxford: Oxford University Press.

Richardson, Kylie. (2007) Case and aspect in Slavic. Oxford: Oxford University Press.

Rivero, María Luisa. (1991) "Long head movement and negation: Serbo-Croatian vs. Slovak and Czech". The linguistic review 8: 319-51.

- (2005) "Topics in Bulgarian morphology and syntax: A minimalist perspective". Lingua 115: 1083-128.

Rivero, María Luisa and Nikolay Slavkov. (2014) "Imperfect(ive) variation: The case of Bulgarian". Lingua 150: 232-277.

Rizzi, Luigi. 1997. "The fine structure of the left periphery". Liliane Haegeman ed. Elements of grammar: Handbook in generative syntax. Dordrecht: Kluwer Academic Publishers, 281-337.

Rudin, Catherine. (1988) "On multiple questions and multiple WH fronting". Natural language and linguistic theory 6(4): 445-501. 
Rudin, Catherine. (2009) "The Bulgarian relative marker -to". Steven Franks, Vrinda Chidambaram, and Brian Joseph, eds. A linguist's linguist: Studies in South Slavic linguistics in honor of E. Wayles Browne. Bloomington, IN: Slavica, 403-22.

. (2013) Aspects of Bulgarian syntax: Complementizers and WH constructions. 2nd revised edition. Bloomington, IN: Slavica.

Runić, Jelena, (2014) A new look at clitics, clitic doubling, and argument ellipsis: Evidence from Slavic. Ph.D. dissertation, University of Connecticut.

Schürcks, Lilia, Anastasia Giannakidou, and Urtzi Etxeberria, eds. (2014) The nominal structure: Slavic and beyond. Berlin: De Gruyter. [Studies in generative grammar.]

Scott, Tanya. (2012) Whoever doesn't HOP must be superior!: The Russian left-periphery and the emergence of superiority. Ph.D. dissertation, Stony Brook University.

Short, David. (1993) "Czech". Bernard Comrie and Greville Corbett, eds. The Slavonic languages. London: Routledge, 455-532.

Slavkov, Nilolay. (2008) "Formal consequences of dative clitic doubling in Bulgarian ditransitives: An applicative analysis". Journal of Slavic linguistics 16(1): 139-66.

Stepanov, Arthur. (1998) On Wh-fronting in Russian". Pius Tamanji and Kiyomi Kusumoto, eds. Proceedings of the North Eastern Linguistic Society 28, University of Toronto. Amherst: GLSA, University of Massachusetts, 453-467.

Stjepanović, Sandra. (1999) What do second-position cliticization, scrambling, and multiple wh-fronting have in common? Ph.D. dissertation, University of Connecticut.

Šimík, Radek. (2014) "Review of Grebenyova (2012)". Journal of Slavic linguistics 22(1): 129-63.

Tasseva-Kurktchieva, Mila. (2004) "Possessives, theta roles, and the internal structure of Bulgarian DPs". Olga Arnaudova, Wayles Browne, Maria Luisa Rivero, and Danijela Stojanović, eds. Formal approaches to Slavic linguistics: The Ottawa meeting 2003. Ann Arbor: Michigan Slavic Publications, 251-68.

Tomić, Olga Mišeska. (1996) "The Balkan Slavic clausal clitics". Natural language and linguistic theory 14(4): 811-72.

Yadroff, Michael. (1999) Formal properties of functional categories: The minimalist syntax of Russian nominal and prepositional expressions. Ph.D. dissertation, Indiana University.

Willer-Gold, et al. (2016) "Morphosyntactic production of coordination agreement in South Slavic: A comparative study". Journal of Slavic linguistics 24(1): 187-224.

Willim, Ewa. (2012) "Concord in Polish coordinate NPs as Agree". Markéta Ziková and Mojmír Dočekal, eds. Slavic languages in formal grammar: Proceedings of FDSL 8.5, Brno, 2010. Frankfurt: Peter Lang, 233-53. 
Witkoś, Jacek. (2009) “Movement, case transmission and case independence in Polish control". Gerhild Zybatow, Uwe Junghanns, Denisa Lenertová, and Petr Biskup, eds. Studies in formal Slavic phonology, morphology, syntax, semantics, and information structure. Proceedings of Formal Approaches to Slavic Linguistics 7, Leipzig 2007. Frankfurt: Peter Lang, 235-52.

- (2010) "On the lack of case on the subject of infinitives in Polish". Folia Linguistica 44(1): 179-237.

- (2016) "Review of Pesetsky (2013)". Journal of Slavic linguistics 24(2): 405-23.

Witkoś, Jacek, Piotr Cegłowski, Anna Snarska, and Sylwiusz Żychliński. (2011) Minimalist facets of control. An English-Polish comparative overview of gerunds and infinitives. Poznań: Wydawnictwo Naukowe UAM.

Zanon, Ksenia. (2015a) On hybrid coordination and quantifier raising in Russian. Ph.D. dissertation, Indiana University.

. (2015b) "Russian anaphoric possessive in context". Małgorzata Szajbel-Keck, Roslyn Burns and Darya Kavitskaya, eds. Formal approaches to Slavic linguistics: The first Berkeley meeting 2014. Ann Arbor: Michigan Slavic Publications, 362-81.

Department of Linguistics

844 Ballantine Hall

Indiana University

Bloomington, IN 47405 USA

franks@indiana.edu 
